\title{
On the transference of the mantids collection (Insecta, Mantodea) from the Entomological Collection of Instituto Butantan to the Museu Nacional, Rio de Janeiro, Brazil
}

\author{
Bernardo Ferraz $^{1 \bowtie \odot}$, Pedro Souza-Dias ${ }^{1 \oplus}$ \& Flávia Virginio ${ }^{2} \odot$
}

1. Museu Nacional, Universidade Federal do Rio de Janeiro, Rio de Janeiro, Brazil. 2. Grupo de Pesquisa em Entomologia Médica; Curadoria da Coleção Entomológica do Instituto Butantan, São Paulo, Brazil.

\section{EntomoBrasilis 14: e958 (2021)}

\section{Edited by:}

Rafael Boldrini

Article History:

Received: 24.vii.2021

Accepted: 06.ix.2021

Published: 23.ix.2021

Corresponding author:

Bernardo Ferraz

७ bernardorferraz99@gmail.com

Funding agencies:

Without funding declared

\begin{abstract}
Brazil is one of the most diverse countries in the world, hosting more than 250 known species of mantids (Mantodea). Studying natural history collections is crucial to identify, describe new taxa and solve taxonomic issues, improving the knowledge about the biodiversity. Here we document the transference of the mantids collection from the Entomological Collection of Instituto Butantan (São Paulo, Brazil) to the Museu Nacional (Rio de Janeiro, Brazil) and provide a morphological assessment on the 33 transferred mantids. We recognized 13 genera and 12 species, with diversified distribution in Brazil, although 6 specimens from 4 genera could not be identified at a specific level. The transference of this collection starts a new phase of restructuration and recognition of the Medical Entomology scope of the donor collection, aside from helping the rebuilt of the Entomological Collection of the Museu Nacional, lost in the 2018 fire, and allowing further researches within the group.
\end{abstract}

Keywords: Curatorship; Hexapoda; Dictyoptera; Insect; Natural history collection. razil hosts about 250 species of mantids grouped into 12 families (OtTe \& Spearman 2005; Rodrigues \& Cancello 2013; Schwarz \& ROY 2019; RIVERA \& SVENSON 2020). In a country that maintains about $10 \%$ of the global entomofauna (RAfael et al. 2009), Brazilian natural history collections are extremely important for entomological studies, especially those focused on poorly studied taxa and with a complicated taxonomic history (e.g., CRISPINo et al. 2020; RIVERA \& SVENSON 2020).

Natural history collections contribute with information about species occurrence, location, time of appearance, life stage, genetic information, and morphological traits (BURRELL et al. 2015; KHAROUBA et al. 2018), providing the information needed to solve and/or base taxonomic studies. These collections often have records of locally or completely extinct species or totally altered locations, being a great tool for defining priority on conservation areas (RodRIGUeS \& CANCELLO 2013). MEINEKE et al. (2018) suggest that, even though the majority of newly described species were found in collections, museum specimens are still underused, notably in ecological studies.

The entomological collections of the Instituto Butantan (IBu) (São Paulo, Brazil) and Museu Nacional (MNRJ) (Rio de Janeiro, Brazil) are centenary. Moreover, both institutions suffered with the tragic power of negligence through the fires of 2010 on the IBu and of 2018 on the MNRJ. Fortunately, in 2010 the entomological collection was allocated at the Parasitology Section and was not befell by the fire - unfortunately the MNRJ collection was not so lucky.

The Entomological Collection of IBu was part of the Parasitology Section since its creation, in the 1910s, to 2013 when a new build was created to host all zoological collections. However, several other adversities befell this collection, and just recently a restructuration has been implemented.

During many years the collection had several informal curators, majoritarian non-entomologist "physicianscientists". However, only when the entomologist Lauro Pereira Travassos Filho was invited by the Institutional Board to take the position of head of this Section in 1969, this collection started to grow up significantly (MARASSÁ \& BARATA 2000).

Currently, this collection has a significant number of specimens of medical importance (vector and toxic insects) since it is the main focus of the institution. Therefore, collections of taxa that do not show medical relevance are not as a representative, even though are centenary, as the Mantodea collection. Thus, the present work aims to report an annotated list of the mantids donated from the Entomological Collection of IBu to the collection of the MNRJ.

\section{MATERIAL AND METHODS}

The individuals were identified up to the species level using dichotomous keys according to each genus as follows: Acanthops Audinet-Serville, 1831 (LOMBARDO \& IPPOLIto 2004); Macromantis Saussure, 1871 (Roy 2002); Miobantia GiglioTos, 1917 (ScherRer 2014); Parastagmatoptera Saussure, 1871 (Lombardo et al. 2015); Stagmatoptera Burmeister, 1838 (Rodrigues \& Cancello 2016); and Zoolea Audinet-Serville, 1839 (Roy \& EHRMAnn 2009). The original descriptions were also used as a complement (e.g., REHN 1911; REHN 1916). When necessary, photographs and/or specimens previously identified were used for comparison.

The animals were observed under a stereomicroscope Motic SMZ-168 and body measures were taken with a caliper. The structures used for identification vary according to the 
group studied. BRANNOCH et al. (2017) was used as a guide for morphological features.

Specimens were photographed with Nikon D3200 with macro lens 'micro Nikkor 60 mm AF-S ED', and an 18\% grey cardboard as background. Photographic material was handled in Adobe Lightroom Classic CC ${ }^{\circledR}$ and Adobe Photoshop CC 2018 ${ }^{\circledR}$ software's. Specimens' coloration was not altered.

\section{RESULTS AND DISCUSSION}

The collection, being restricted to a random collection of specimens sampled by several people and coming from several localities, has 33 individuals mounted on entomological pins and does not represent type specimens. Two specimens, namely Macromantis ovalifolia (Stoll, 1813) [N011104] and Stagmatoptera supplicaria (Burmeister, 1838) [N011107], will remain in the IBu collection as they are part of a still ongoing project.

The 33 mantids specimens here are classified in five Neotropical families, 13 genera and 12 identified species (Table 1): Acanthopidae (Acanthops Audinet-Serville, 1831; Metilia Stål, 1877); Coptopterygidae (Brunneria Saussure, 1869); Photinaidae (Macromantis Saussure, 1871; Photiomantis Piza, 1968); Thespidae (Eumusonia Giglio-Tos, 1916; Miobantia Giglio-Tos, 1917; Thesprotia Stål, 1877); and Mantidae (Oxyopsis Caudell, 1904; Parastagmatoptera Saussure, 1871; Pseudovates Saussure, 1869; Stagmatoptera Burmeister, 1838; Zoolea Audinet-Serville, 1838). Specimens of Eumusonia, Metilia, Pseudovates, Thesprotia and a Zoolea nymph could not be identified to a specific level with individual situations detailed in the section below. Below we provide an annotated list of the identified species (Table 1).

\section{Family Acanthopidae}

\section{Acanthops Audinet-Serville, 1831 (Figure 1A)}

Acanthops has been fully revised by LOMBARDO \& IPPOLITO (2004) and is the type genus in the family Acanthopidae. It's distributed in warm, humid habitats in the North of the Neotropic with size varying between $38-50 \mathrm{~mm}$, being the most specious genus in the family with 16 valid species (RIVERA \& SVEnson 2020). Rivera \& SVEnson (2020) made a comment about the distribution of the species of Acanthops with a remark on Acanthops falcataria (Goeze, 1778) which occurs in Southeastern Brazil, which is the species present in the group of specimens donated by IBu.

\section{Metilia Stål, 1877 (Figure 1B)}

Metilia was revised by MALDANer (2014) in a master's dissertation, but this study included only adult males, and the data was not formally published. Its distributions are restricted to the North of the Neotropic, from Costa Rica to the Amazon basin, sizes varying from $25-40 \mathrm{~mm}$ and only four valid species (RIVERA \& SVEnsOn 2020). Since the specimen is a female, it was not possible to carry out a specific identification with Maldaner's work.

Maldaner (2014) did an enormous revision in Metilia taxonomy based on morphological characters of 160 specimens from several places, thus having the following conclusion: Revalidation of two species previously assigned as synonyms; transference of two species to Metilia, formally transferred by Rivera \& SvEnson (2020) as Metilia coloradensis (Gonzáles, Miller \& Salazar, 2012) and Metilia septenspinoso (Ippolito, 2007), described six new species within the genus, and described a new genus. More comments about this work are presented in RIVERA \& VERGARA-COBIÁN (2017).

\section{Family Coptopterygidae}

\section{Brunneria Saussure, 1869 (Figure 1C)}

Brunneria is a conspicuous mantis genus with large specimens achieving 60-98 $\mathrm{mm}$ and swollen basal antennal flagellomeres but only with five species described, four of them up to 1915 and one in 2002 (Agudelo \& ChicA 2002; RiverA \& SVENSON 2020). Brunneria has a key for species in Agudelo \& CHICA 2002, although the key was assembled without a revision of the group, based on the work of GIGLIO-Tos (1927). A complementary comparison with the original descriptions of the species was made (SAUSSURE 1870), allowing the identification as Brunneria brasiliensis Saussure, 1870.

\section{Family Photinaidae}

\section{Macromantis Saussure, 1871 (Figure 1D)}

Macromantis is one of the largest praying mantises in the Neotropics, having the largest body mass within the neotropical taxa, achieving 80-110 mm, usually with vibrant green coloration (Roy 2002). The genus has only four valid species, three of them occurring in Brazil (RIverA \& SVENSON 2020). All species are easily identifiable using Roy's work, which made it possible to identify the specimen presented at this work as Macromantis ovalifolia (Stoll, 1813), probably the most common of the species within the genus.

\section{Photiomantis Piza,1968 (Figure 2A)}

Photiomantis is a small genus with only two valid species for Northeastern Brazil, but with a complicated taxonomic history due to many erroneous nomenclatural procedures (KoçaK \& Kemal 2008; Özdikmen 2008; Rivera 2010a; Agudelo \& Rivera 2015; Rivera \& SVEnson 2020). Both species of the genus have a huge temporal disparity of a hundred years between each other, Photiomantis planicephala (Rehn, 1916) and Photiomantis nigrolineata (Menezes \& Bravo, 2015), and the comparison with both descriptions (REHN 1916; Menezes \& Bravo 2015) made clear that the specimen in the collection is P. planicephala.

\section{Family Thespidae}

\section{Eumusonia Giglio-Tos, 1916 (Figure 2B)}

Eumusonia species have many external morphological similarities, a problematic taxonomic history that does not allow any precise identification, and no reviews across its history (RIVERA \& SVENSON 2020). The genus needs to be revised, and RIVERA \& SVENSON (2020) identified seven non-described species in the analysis of material based on male genitalia, corroborating with this need for an urgent taxonomic revision. Thus, here we decided to keep Eumusonia restricted to a generic identification.

\section{Miobantia Giglio-Tos, 1917 (Figure 2C-D)}

Miobantia is composed of small individuals with $16-26 \mathrm{~mm}$ and usually found in low vegetation across the Brazilian southeastern Atlantic rainforests up to Paraguay and Argentina (Scherrer 2014; Scherrer \& Agudelo 2019). The genus has 11 valid species, 9 present on a thorough review (SCHERRER 2014), one recently described (SCherRer \& Agudelo 2019) and the most recent inclusion was the analyzes of Promiopteryx punctata and later transference to Miobantia as Miobantia punctata (Giglio-Tos, 1917) by RIVERA \& SVENSON (2020) who also highlight that its status as a valid species needs verification.

As the site of collection is São Paulo, the dichotomous key presented in SCHERRER (2014) was used and we found out that our specimens are in the general morphological spectrum of 
a group that includes Miobantia ciliata (Stål, 1860), Miobantia phryganea (Saussure, 1869) and Miobantia rustica (Fabricius, 1781). As all three specimens are registered to São Paulo, a morphological assessment using male genitalia was tried, but due to specimen's integrity, only one male was successfully dissected and identified as M. rustica. As all specimens have the same collection site despite the year of collection, we considered all other specimens as $M$. cf. rustica.

\section{Thesprotia Stål, 1877 (Figure 3A)}

Thesprotia is one the most diverse Thespidae genera with 15 valid species widespread across the Americas; it is easily found in entomological collections and its size varies from 35-65 mm, having a slender stick-like appearance and a conspicuous harpoon shaped foretibia (RIVERA \& SVENSON 2020). Rivera \& SVEnson (2020) remark that Thesprotia is one of the least studies Thespidae genera and the literature does not represent the actual variety within the genus, that is in need of a revision. Due to both specimens being females, a specific identification was not possible.

\section{Family Mantidae}

\section{Oxyopsis Caudell, 1904 (Figure 3B)}

Oxyopsis is a poorly studied genus, with 11 described species which have been reviewed and only one species, Oxyopsis festae Giglio-Tos, 1914, had the male genitalia described (RIVERA 2010b; Lombardo \& AGABITI 2001). In the case of specimens of present work, both were identified as Oxyopsis media Stål, 1877. This species is described for "San Paolo, Brasilie" by STÁL (1877), and REHN (1911) confirms the location by calling it "São Paulo", in the southeastern Brazilian region; adding the description of the male by GIGLIO-Tos (1914) and comparing the measures indicated, it was possible to identify the species.

\section{Parastagmatoptera Saussure, 1871 (Figure 3C-D)}

Parastagmatoptera is a medium-sized mantid genus that is distributed across South America and has been recently reviewed by LOMBARDO et al. (2015), who conducted an excellent morphological investigation for all known species. This same work provides a dichotomous key that was used to identify the specimens as Parastagmatoptera unipunctata (Burmeister, 1838), which appears to be the most common species in Southeast Brazil.

\section{Pseudovates Saussure, 1869 (Figure 4A)}

Pseudovates is a diverse genus with 24 described species present from the south of the United States and goes all of South America with some of the largest Mantodea species (SVEnson et al. 2016). The genus does not have revisions beyond their original descriptions, only studies that added or removed species from this genus, even though the Vatinae subfamily has a phylogenetic review covering the lineages of the group, thus encompassing Pseudovates in the work of SVEnson et al. (2016). This same work synonymized Hagiotata Saussure \& Zehntner, 1894 and Phyllovates Kirby, 1904 to Pseudovates including several species to it.

Because many species descriptions of these genera are old, vague and lack diagnostic characters, the identification through those texts is complex and this taxon needs to be reviewed. The male genitalia have been dissected and compared with the original descriptions but many of them lack genitalia description and illustrations, so a specific identification was not possible.
Stagmatoptera Burmeister, 1838 (Figure 4B-D, Figure 5A-B)

Stagmatoptera is a well-known genus easily recognizable for its large body size $(49-98 \mathrm{~mm})$ and conspicuous forewings marks, being found across all South America up to Panama, being commonly found in entomological collections (RIverA $2010 \mathrm{~b})$. It is one of the most diverse Neotropical Mantidae, with 14 valid species, two of which are species inquirenda (Stagmatoptera abdominalis (Olivier, 1792) \& Stagmatoptera indicator (Olivier, 1792)) and have been recently reviewed by Rodrigues \& CANCELLO (2016), providing a key to its species.

The genus Stagmatoptera is the most abundant and diverse among the specimen pool of the present collection analyzed with nine specimens distributed in four species, representing $27,3 \%$ of all specimens. Stagmatoptera hyaloptera (Perty, 1832) and Stagmatoptera precaria (Linnaeus, 1758) are the most representatives with four and three specimens respectively while Stagmatoptera binotata Scudder, 1869 and Stagmatoptera supplicaria (Burmeister, 1838) only have one specimen each.

\section{Zoolea Audinet-Serville, 1838 (Figure 5C-D)}

Zoolea is a conspicuous genus among Neotropical mantids because of its morphology, being a large-sized mantis varying from 55-90 $\mathrm{mm}$ full of projection along the body, a conspicuous horn-like ocellar tubercle and can be found from Argentina to Northern South America (Roy \& EHRMAnN 2009; SVENSON et al. 2016). The genus comprises five valid species and received a complete taxonomic revision by Roy \& EHRMANN (2009).

Regarding the two specimens of Zoolea present on this collection analyzed, both are a female: an adult and a nymph. The identification of the adult was possible due to the key present in Ror \& EHrmann (2009) as Zoolea major Giglio-Tos, 1914, but the authors do not comment on nymphs, making any specific identification of the specimen an assumption that is probably erroneous.

The majority of the specimens were collected in Southeast Brazil (20 individuals, 60,6\%), almost all of them (19 specimens) were collected in São Paulo State. Although the majority of species is currently labeled with the locality, ten specimens $(30,3 \%)$ does not have a specific collection site assigned to them: Brunneria brasiliensis, both Photiomantis planicephala, all Stagmatoptera hyaloptera and Stagmatoptera precaria are labeled only as Brazil, the label of the female Metilia sp. does not have a country assigned for its collection, and two specimens, a male Eumusonia sp. and a male Oxyopsis media are labeled as "Brasília-DF; São Paulo-SP" and was not possible to determinate their origin. Even though those specimens do not have a specific collection site, their incorporation into the collection of the Museu Nacional can help in further morphological and morphometric studies.

Another issue observed in the collection is the lack of precise dates in some specimens: $24,2 \%$ (8 specimens) of all specimens do not have an accurate collection date and most of them also do not have a site of collection assigned. The ones assigned with a precise date (at least the month of collection) were collected from 1970 to 2011, and 76,9\% (20 specimens) of those were collected between the '70s and ' $80 \mathrm{~s}$ regardless of location or genera.

The difficulty in the specific identification of insects is the reality of many taxa, especially those who have been historically poorly studied. In the case of Neotropical mantids, there is a continuous increase in the published works in recent years (RIVERA 2010b), but much remains to be done to clarify important taxonomic issues. Several genera 


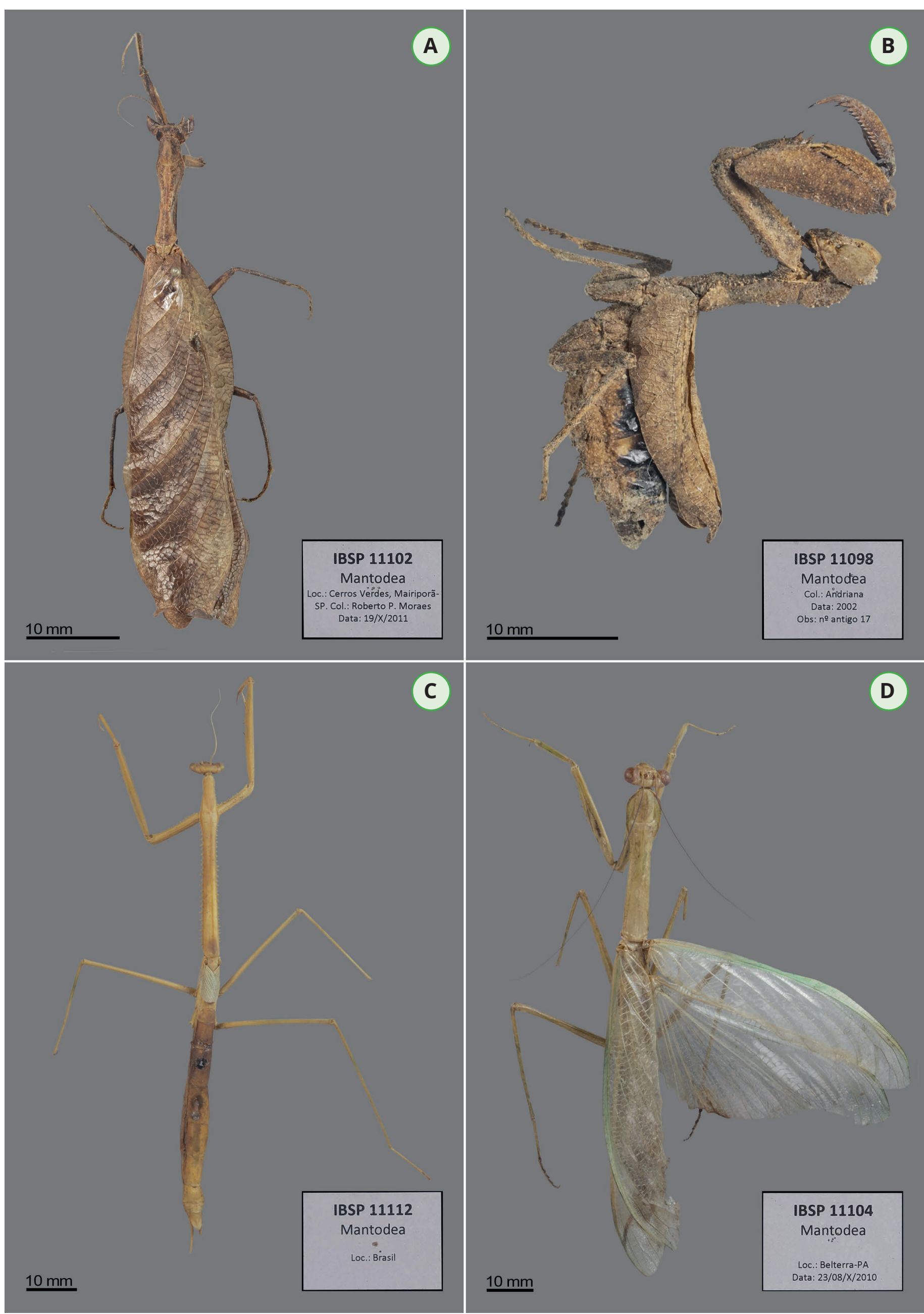

Figure 1. (A) Male of Acanthops falcataria; (B) Female of Metilia sp.; (C) Female of Brunneria brasiliensis; (D) Male of Macromantis ovalifolia. Source: Authors. 


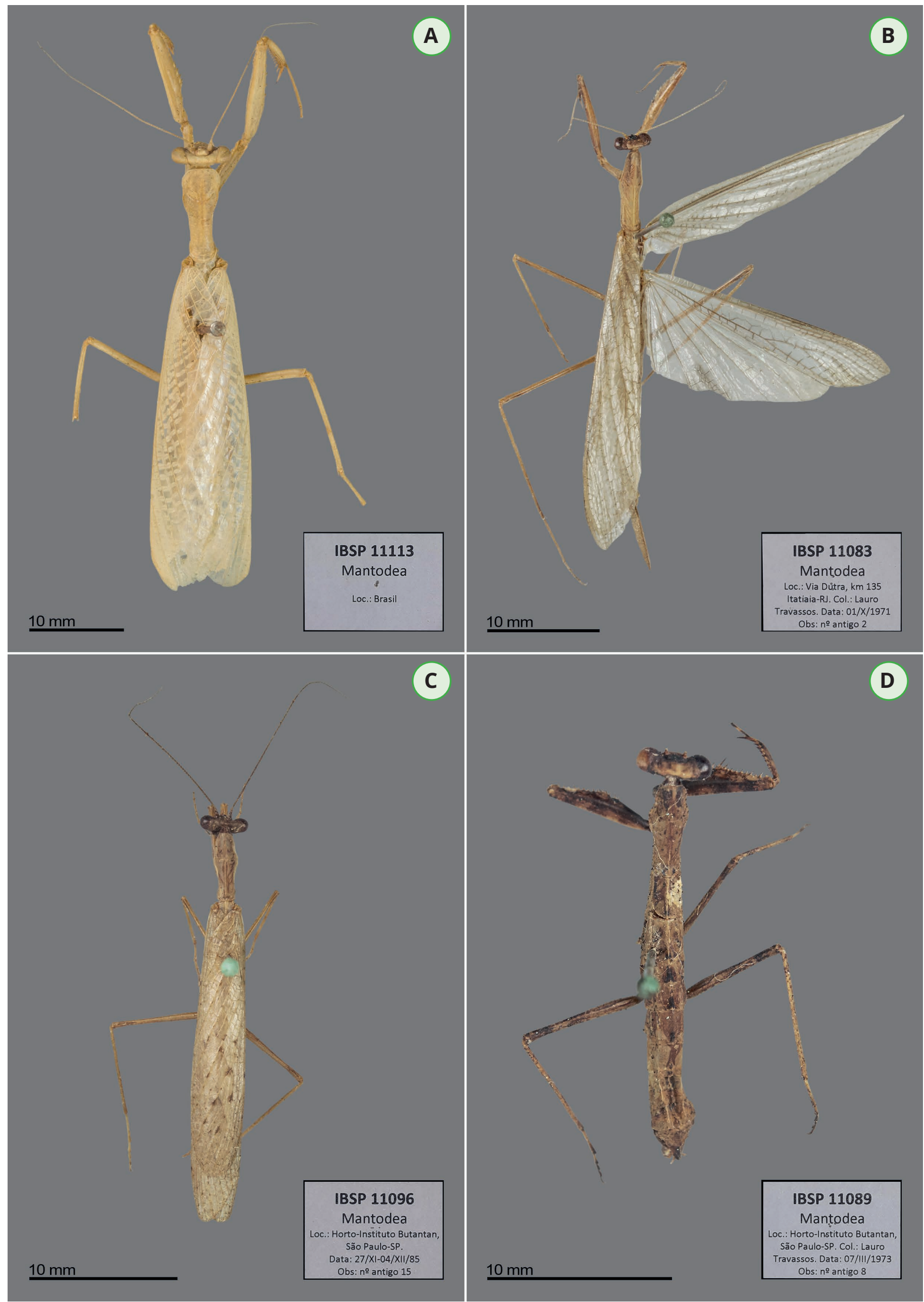

Figure 2. (A) Male of Photiomantis planicephala; (B) Male of Eumusonia sp.; (C) Male of Miobantia cf. rustica; (D) Female of Miobantia cf. rustica. Source: Authors. 


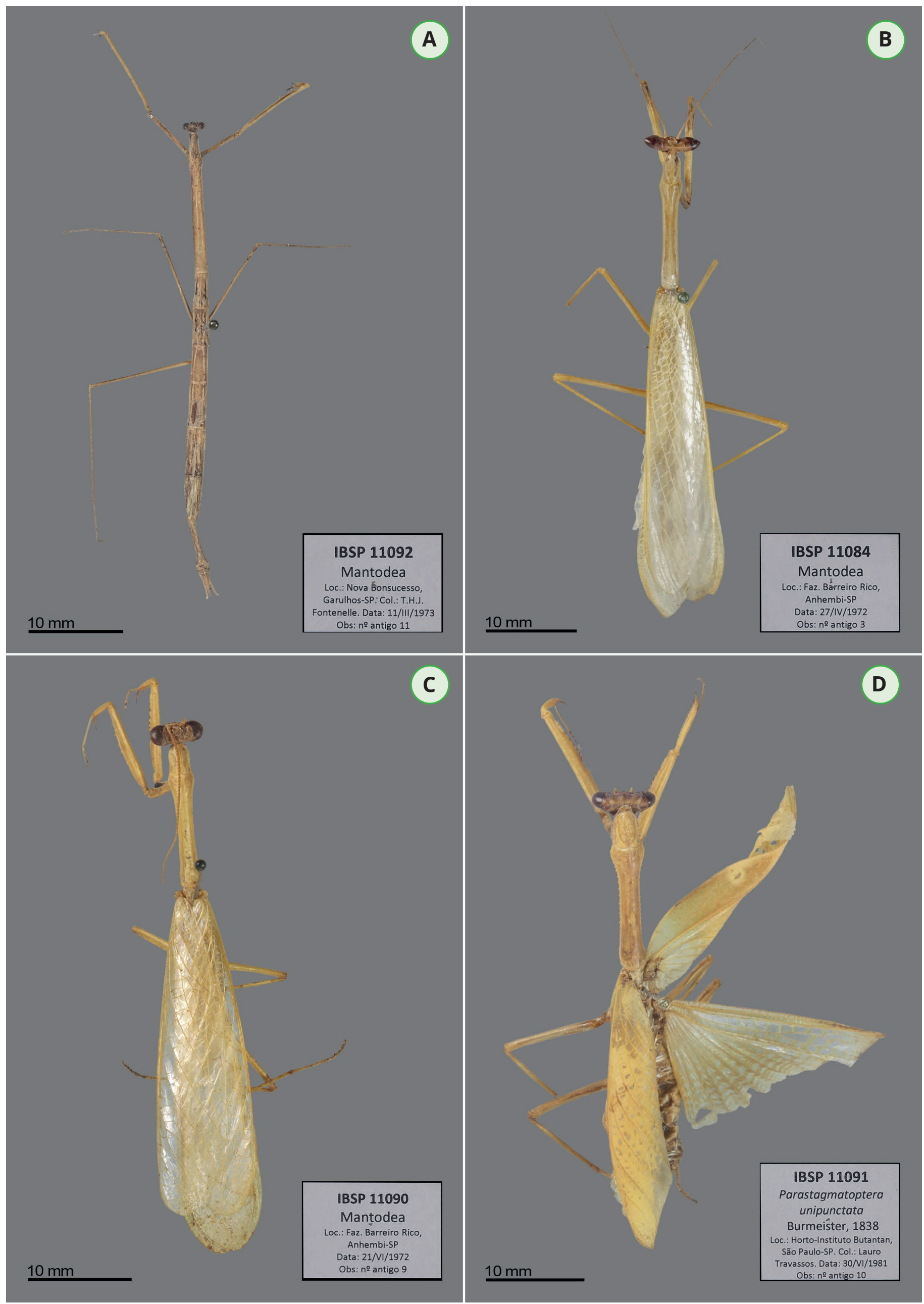

Figure 3. (A) Female of Thesprotia sp.; (B) Male of Oxyopsis media; (C) Male of Parastagmatoptera unipunctata; (D) Female of Parastagmatoptera unipunctata. Source: Authors. 


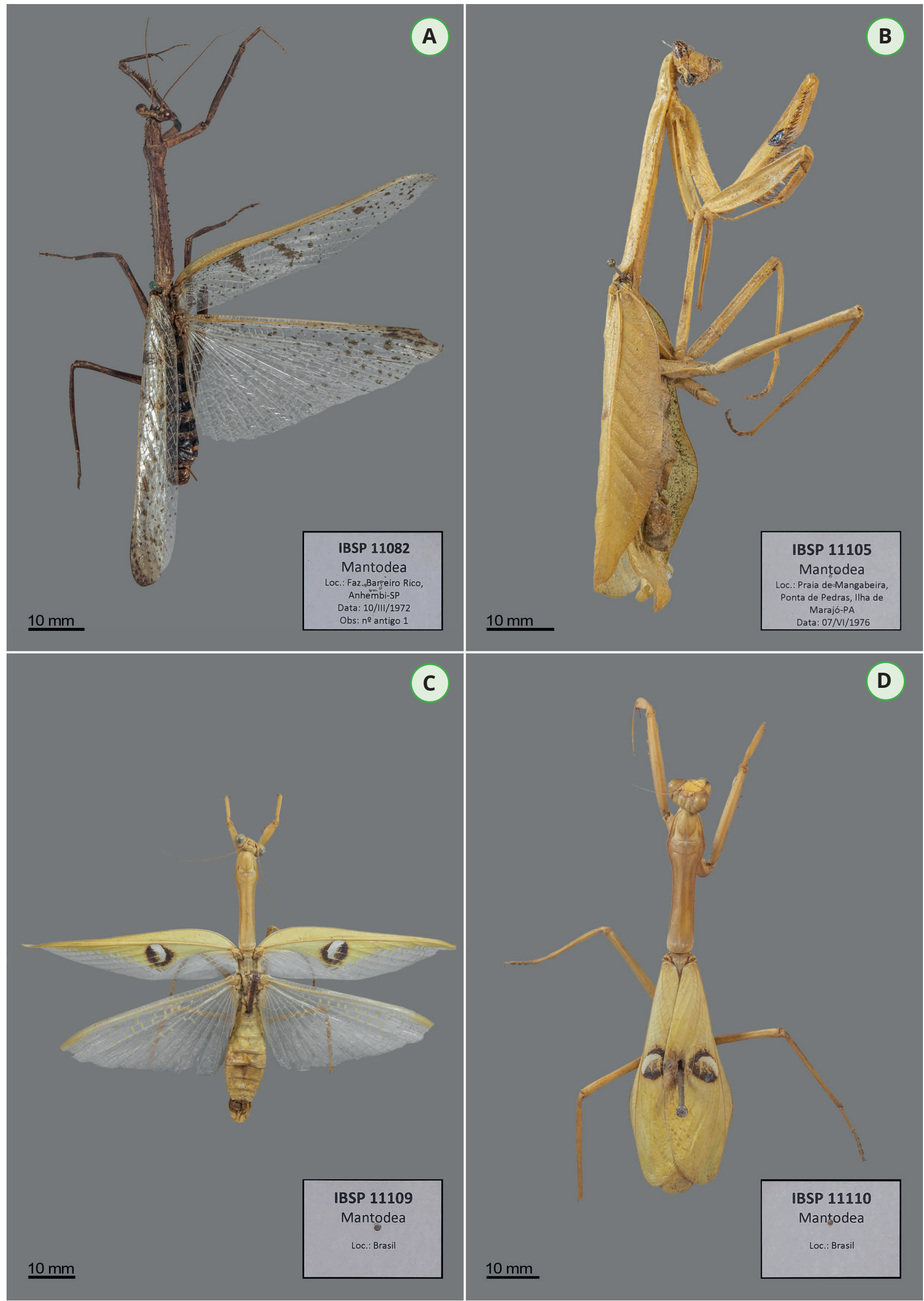

Figure 4. (A) Male of Pseudovates sp.; (B) Female of Stagmatoptetra binotata; (C) Male of Stagmatoptera hyaloptera; (D) Female of Stagmatoptera hyaloptera. Source: Authors. 


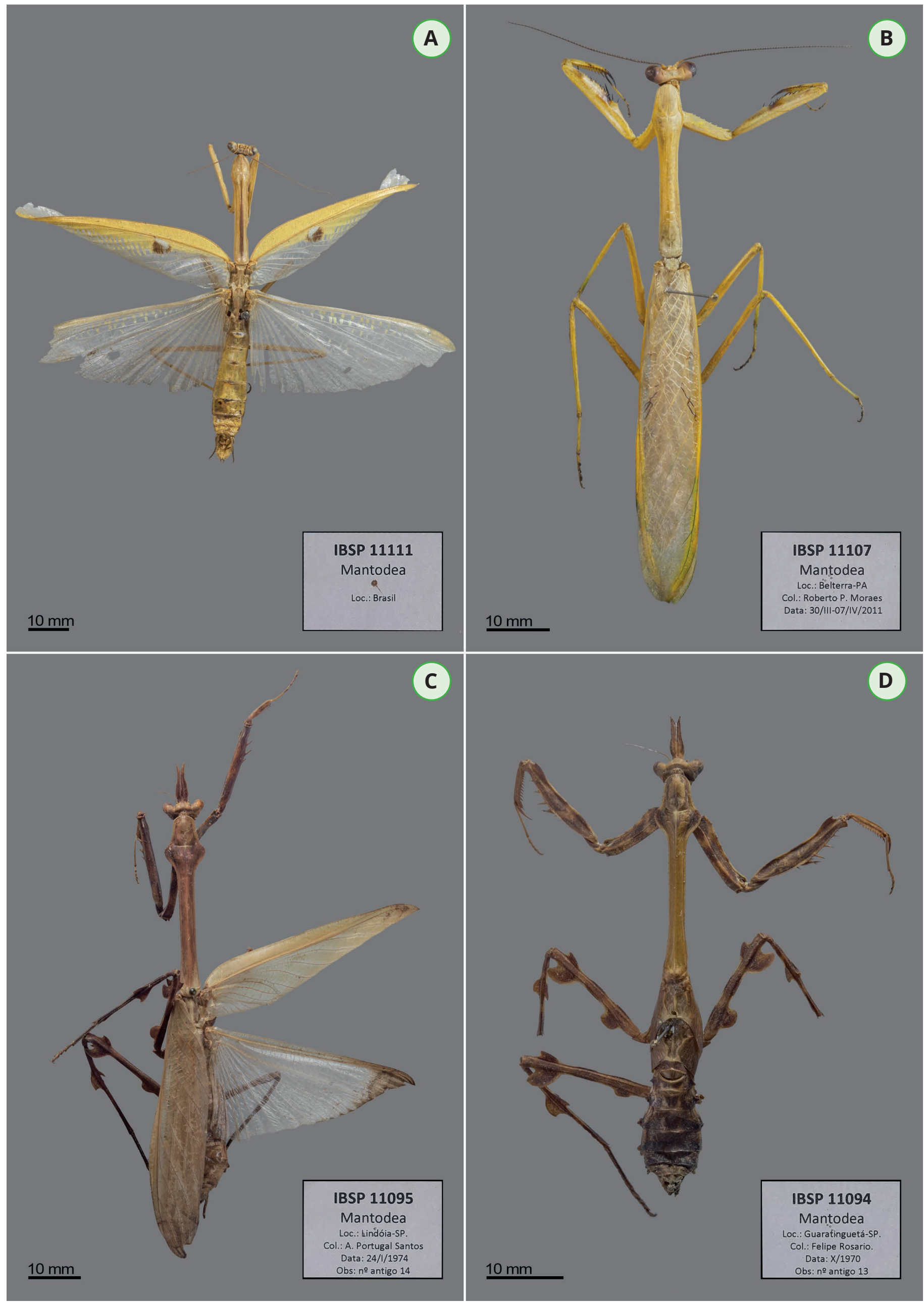

Figure 5. (A) Male of Stagmatoptera precaria; (B) Male of Stagmatoptera supplicaria; (C) Female of Zoolea sp.; (D) Female of Zoolea sp. nymph. Source: Authors. 
have a taxonomy and systematics that remain enigmatic, such as the family Thespidae and Mantidae. Thus, the study of collections is a crucial factor in solving these questions (Meineke et al. 2018).

We highlight the importance of the incorporation of this Mantodea collection into the collection of the Departamento de Entomologia do Museu Nacional (MNRJ), a collection that is being rebuilt since the tragic fire of 2018. This collection will increase the new Mantodea collection of MNRJ, allow future studies on taxonomy/systematics of mantids, and also be useful for the formation of specialized human resources through the Zoology Graduate Program of the Museu Nacional.

Table 1. Species of mantis deposited in the entomological collection of the Butantan Institute, organized by family with the number of specimens in parentheses. Some species have specimens collected from different Brazilian States, those assigned as: DF - Distrito Federal; PA - Pará; RJ - Rio de Janeiro; SP - São Paulo. Source: Authors.

\begin{tabular}{|c|c|c|c|c|c|}
\hline Species & Author-Year & $\mathbf{N}^{\circ}$ & Locality & Date & Sex \\
\hline \multicolumn{6}{|l|}{ Acanthopidae (2) } \\
\hline Acanthops falcataria & (Goeze, 1778) & 11102 & Mairiporã/SP & 19.x.2011 & $\hat{0}$ \\
\hline Metilia sp. & Stål, 1877 & 11098 & - & _._.2002 & o \\
\hline \multicolumn{6}{|l|}{ Coptopterygidae (1) } \\
\hline Brunneria brasiliensis & Saussure, 1870 & 11112 & Brasil & - & q \\
\hline \multicolumn{6}{|l|}{ Photinaidae (3) } \\
\hline Macromantis ovalifolia & (Stoll, 1813) & 11104 & Belterra/PA & 23.ix-08.x.2010 & $\hat{0}$ \\
\hline Photiomantis planicephala & (Rehn, 1916) & 11113 & Brazil & - & $\hat{\sigma}$ \\
\hline Photiomantis planicephala & (Rehn, 1916) & 11114 & Brazil & - & $\hat{\sigma}$ \\
\hline \multicolumn{6}{|l|}{ Thespidae (10) } \\
\hline Eumusonia sp. & Giglio-Tos, 1916 & 11083 & Itatiaia/RJ & 01.x.1971 & $\hat{\sigma}$ \\
\hline Eumusonia sp. & Giglio-Tos, 1916 & 11087 & Brasília-DF; São Paulo-SP & 10.viii.1972 & $\hat{\sigma}$ \\
\hline Miobantia cf. rustica & (Fabricius, 1781) & 11089 & Butantã/SP & 07.iii.1973 & q \\
\hline Miobantia rustica & (Fabricius, 1781) & 11085 & Butantã/SP & _.vi.1974 & $\hat{0}$ \\
\hline Miobantia cf. rustica & (Fabricius, 1781) & 11086 & Butantã/SP & 17.viii.1974 & $\hat{0}$ \\
\hline Miobantia cf. rustica & (Fabricius, 1781) & 11096 & Butantã/SP & 27.xi-04.xii.1985 & $\hat{0}$ \\
\hline Miobantia cf. rustica & (Fabricius, 1781) & 11097 & Butantã/SP & 19-26.xi.1985 & $\hat{0}$ \\
\hline Miobantia cf. rustica & (Fabricius, 1781) & 11100 & Butantã/SP & 27.vi.1977 & $\hat{\sigma}$ \\
\hline Thesprotia sp. & Stål, 1877 & 11092 & Guarulhos/SP & 11.iii.1973 & q \\
\hline Thesprotia sp. & Stål, 1878 & 11093 & Butantã/SP & 31.iii.1974 & q \\
\hline \multicolumn{6}{|l|}{ Mantidae (17) } \\
\hline Oxyopsis media & Stål, 1877 & 11084 & Anhembi/SP & 27.iv.1972 & $\hat{0}$ \\
\hline Oxyopsis media & Stål, 1877 & 11088 & Brasília-DF; São Paulo-SP & 10.vii.1972 & $\hat{0}$ \\
\hline Parastagmatoptera unipunctata & (Burmeister, 1838) & 11091 & Butantã/SP & 30.vi1981 & q \\
\hline Parastagmatoptera unipunctata & (Burmeister, 1838) & 11090 & Anhembi/SP & 21.vi.1972 & $\hat{\sigma}$ \\
\hline Parastagmatoptera unipunctata & (Burmeister, 1838) & 11103 & São Paulo/SP & 23.iii.2016 & $\hat{0}$ \\
\hline Pseudovates sp. & Saussure, 1869 & 11082 & Anhembi/SP & 10.iii.1972 & $\hat{\sigma}$ \\
\hline Stagmatoptera binotata & Scudder, 1869 & 11105 & Ilha de Marajó/PA & 07.vi.1976 & q \\
\hline Stagmatoptera hyaloptera & (Perty, 1832) & 11110 & Brazil & - & 우 \\
\hline Stagmatoptera hyaloptera & (Perty, 1832) & 11109 & Brazil & - & $\hat{0}$ \\
\hline Stagmatoptera hyaloptera & (Perty, 1832) & 11108 & Brazil & - & $\hat{\sigma}$ \\
\hline Stagmatoptera precaria & (Linnaeus, 1758) & 11099 & Butantã/SP & _.vii.2002 & $\hat{\sigma}$ \\
\hline Stagmatoptera precaria & (Linnaeus, 1758) & 11101 & Butantã/SP & 12.iii.1976 & $\delta$ \\
\hline Stagmatoptera precaria & (Linnaeus, 1758) & 11106 & Butantã/SP & 06.vi.1976 & 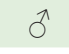 \\
\hline Stagmatoptera precaria & (Linnaeus, 1758) & 11111 & Brazil & - & $\hat{0}$ \\
\hline Stagmatoptera supplicaria & (Burmeister, 1838) & 11107 & Belterra/PA & 30.iii-07.iv.2011 & $\hat{0}$ \\
\hline Zoolea major & Giglio-Tos, 1914 & 11095 & Lindóia/SP & 24.i.1974 & $\hat{0}$ \\
\hline Zoolea sp. & Audinet-Serville, 1838 & 11094 & Guaratinguetá/SP & _.x.1970 & o \\
\hline
\end{tabular}

\section{ACKNOWLEDGMENTS}

We would like to thank entomological collection technician OLIVEIRA EC for the preparation of the material before we started working with it and SCHERRER MV for the guidance for the identification of Miobantia.

\section{REFERENCES}

Agudelo, AA \& LM Chica, 2002. Una nueva especie de Brunneria Saussure, 1869 de Colombia (Mantodea: Vatidae: Photininae). Boletín Cientifico Del Museo de Historia Natural Universidad de Caldas, 6: 83-89. 
Agudelo AA \& J Rivera, 2015. Some taxonomic and nomenclatural changes in American Mantodea (Insecta, Dictyoptera) - Part I. Zootaxa, 3936: 335-356. DOI: https://doi.org/10.11646/zootaxa.3936.3.2

Brannoch, SK, F Wieland, J Rivera, KD Klass, O Béthoux \& G Svensonk, 2017. Manual of praying mantis morphology, nomenclature, and practices (Insecta, Mantodea). ZooKeys, 696: 1-100. DOI: https://doi.org/10.3897/ zookeys.696.12542

Burrel, AS, TR Disotell \& CM Bergey, 2015. The use of museum specimens with high-throughput DNA sequencers. Journal of Human Evolution, 0: 35-44. DOI: https://doi.org/10.1016/j.jhevol.2014.10.015

Crispino, EB, PI Chiquetto-Machado, PW Engelking \& EM Cancello, 2020. Contributions to the knowledge of Canuelios Stål (Phasmatodea: Heteronemiidae): taxonomy, morphology and notes on the biology of two species. Zootaxa, 4743: 511-535. DOI: https://doi.org/10.11646/ zootaxa.4743.4.3

Giglio-Tos, E, 1914. Mantidi Esotici - Vatinae. Bollettino dei Musei di Zoologia ed Anatomia comparata, 684: 1-87.

Giglio-Tos, E, 1927. Das Tierreich. Orthoptera-Mantidae. Berlim, Walter de Gruyter \& Co.

Lombardo, F \& B Agabiti, 2001. The mantids from Ecuador, with some biogeographic considerations. Journal of Orthoptera Research, 10: 89-104.

Lombardo, F \& S Ippolito, 2004. Revision of the species of Acanthops Serville 1831 (Mantodea, Mantidae, Acanthopinae) with comments on their phylogeny. Annals of the Entomological Society of America, 97: 1076-1102. DOI: https://doi.org/10.1603/00138746(2004)097[1076:ROTSOA]2.0.CO;2

Lombardo, F, R Umbriaco \& S Ippolito, 2015. Taxonomic revision of the Neotropical genus Parastagmatoptera Saussure, 1871 (Dictyoptera, Mantidae, Stagmatopterinae) with a biogeographic comment. Insect Systematics and Evolution, 46: 221-267. DOI: https://doi.org/10.1163/1876312X-45032117

Kharouba, HM, JMM Lewthwaite, R Guralnick, JT Ker \& M Vellend, 2018. Using insect natural history collections to study global change impacts: challenges and opportunities. Philosophical Transactions of the Royal Society B, 374: 1-10. DOI: https://doi.org/10.1163/1876312X-45032117

Koçak, AO \& M Kemal, 2008. Two replacement names in the genus group taxa of Dictyoptera from Colombia and Arabian Peninsula. Centre for Entomological Studies Ankara, Miscelaneous Papers, 141: 6

Maldaner, C, 2014. Revisão taxonômica de Metilia Stål, 1877 (Mantodea: Acanthopidae) e descrição de um gênero novo. Dissertation (Master in Biological Sciences: Entomology). Instituto Nacional de Pesquisas da Amazônia.

Marassá, AM \&JMS Barata, 2000. Nota sobre tipos e espécimes de triatomíneos depositados na Coleção Entomológica do Instituto Butantan, São Paulo (Hemiptera: Reduviidae). Revista da Sociedade Brasileira de Medicina Tropical, 33: 227-230.

Meineke, EK, TJ Davies, BH Daru \& CC Davis, 2018. Biological collections for understanding biodiversity in the Anthropocene. Philosophical Transactions of the Royal Society B, 374: 20170386. DOI: https://doi.org/10.1098/ rstb.2017.0386

Menezes, EC \& F Bravo, 2015. A new species of Margaromantis Piza, 1982 (Insecta: Mantodea) from Brazil. Biodiversity Data Journal, 3: e4343. DOI: https://doi.org/10.3897/ BDJ.3.e4343

Otte, D \& L Spearman, 2005. Mantida Species File, Catalog of the Mantids of the World. Insect Diversity Association Publication, 1: 1-489.

Özdikmen, H, 2008. A substitute name for Rehniella Lombardo, 1999 (Mantodea, Mantidae). Munis Entomology \& Zoology Journal, 3: 765-766.
Rafael, JA, AP Aguiar \& DS Amorim, 2009. Knowledge of insect diversity in Brazil: challenges and advances. Neotropical Entomology, 38: 565-570. DOI: https://doi.org/10.1590/ s1519-566×2009000500001

Rehn, JAG, 1911. Orthoptera - Familia Mantidæ, Subfamilia Vatinæ. Philadelphia, Bibliotheca Regia Monagensis.

Rehn, JAG, 1916. The Stanford Expedition to Brazil, 1911 Dermaptera and Orthoptera I. Transactions of the American Entomological Society, 42: 215-308.

Rivera, J, 2010a. Lost and found: Rediscovery of the genus Margaromantis Piza, 1982 and consequential nomenclatural changes in the genus Colombiella Koçak \& Kemal, 2008 (Mantodea: Mantidae, Photinainae). Zootaxa, 2529: 65-68.

Rivera, J, 2010b. A historical review of praying mantid taxonomy and systematics in the Neotropical Region: State of knowledge and recent advances (Insecta: Mantodea). Zootaxa, 2638: 44-64.

Rivera, J \& C Vergara-Cobián, 2017. A checklist of the praying mantises of Peru: new records, one new genus (Piscomantis gen. n.) and biogeographic remarks (Insecta, Mantodea). Zootaxa, 4337: 361-389. DOI: https://doi.org/10.11646/ zootaxa.4337.3.3

Rivera, J \& GJ Svenson, 2020. The Neotropical "Polymorphic Earless Praying Mantises" - Part II: A taxonomic review of the genera and checklist of species (Insecta: Mantodea, Acanthopoidea). Annapolis, Thomas Say Publications in Entomology.

Rodrigues, HM \& EM Cancello, 2013. Mantodea (Insecta) collection in the Museu de Zoologia da Universidade de São Paulo: Taxonomic and geographical coverage. Check List, 9(5): 957-965. DOI: https://doi.org/10.15560/9.5.957

Rodrigues, HM \& EM Cancello, 2016. Taxonomic revision of Stagmatoptera Burmeister, 1838 (Mantodea: Mantidae, Stagmatopterinae). Zootaxa, 4183: 1-78. DOI: https://doi.org/10.11646/zootaxa.4183.1.1

Roy, R, 2002. Révision du genre néotropical Macromantis Saussure, 1871 (Dictyoptera, Mantidae). Bulletin de la Société Entomologique de France, 107: 403-418.

Roy, R \& R Ehrmann, 2009. Révision du genre Zoolea AudinetServille (Mantodea, Mantidae, Vatinae). Revue Française d'Entomologie, 31: 1-22.

Saussure, H, 1870. Additions au Système des Mantides. Mittheilungen der Schweizer Entomologisehen Gesellsehaft, 3: 221-244.

Scherrer, MV, 2014. A revision of Miobantia Giglio-Tos, 1917 (Mantodea: Thespidae, Miobantiinae), with molecular association of dimorphic sexes and immature stages. Zootaxa, 3797: 207-268. DOI: https://doi.org/10.11646/ zootaxa.3797.1.15

Scherrer, MV \& AA Agudelo, 2019. A new species of Miobantia Giglio-Tos, 1917 with novel morphological feature (Mantodea: Thespidae: Miobantiinae). Zootaxa, 4555: 283286. DOI: https://doi.org/10.11646/zootaxa.4555.2.10

Schwarz, CJ \& R Roy, 2019. The systematics of Mantodea revisited: an updated classification incorporating multiple data sources (Insecta: Dictyoptera). Annales de La Societe Entomologique de France, 55: 101-196. DOI: https://doi.org/10.1080/00379271.2018.1556567.

Stål, C, 1877. Systema Mantodeorum. Essai d'une Systematization nouvelle des Mantidees. Bihang till Kongliga Svenska Vetenskaps-Akademiens Handlingar 4: $1-91$.

Svenson, GJ, C Medellin \& CE Sarmiento, 2016. Re-evolution of a morphological precursor of crypsis investment in the newly revised horned praying mantises (Insecta, Mantodea, Vatinae). Systematic Entomology, 41: 229-255. 

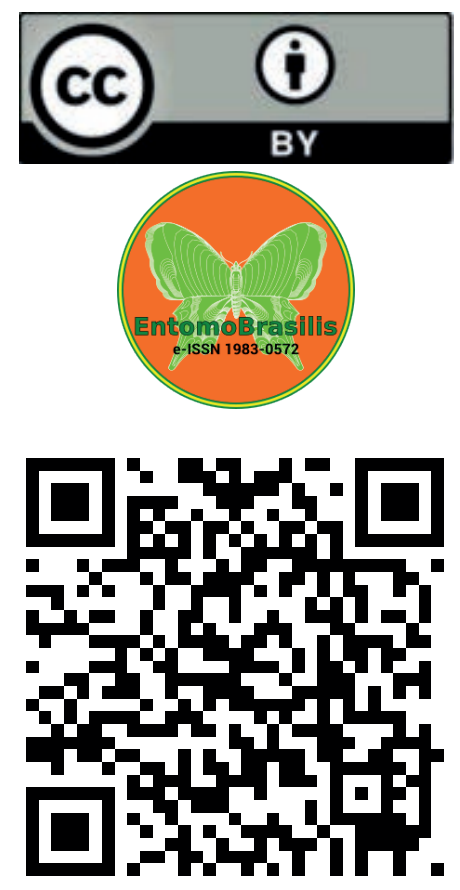